\title{
Pituitary growth hormone release and gene expression in cafeteria-diet-induced obese rats
}

\author{
X Zhou, J De Schepper ${ }^{1}$, D De Craemer ${ }^{2}$, M Delhase, G Gys, \\ J Smitz ${ }^{3}$ and E L Hooghe-Peters
}

Departments of Pharmacology, ${ }^{1}$ Pediatrics, ${ }^{2}$ Anatomy and ${ }^{3}$ RIA, Faculty of Medicine, Free University of Brussels, Brussels, Belgium

(Requests for offprints should be addressed to E L Hooghe-Peters, Department of Pharmacology, Faculty of Medicine, Free University of Brussels, Laarbeeklaan 103, 1090 Brussels, Belgium)

\begin{abstract}
In human obesity as well as in rat obesity models a decrease in spontaneous and stimulated GH secretion has been a constant finding. The presence of a decreased pituitary $\mathrm{GH}$ synthesis in diet-induced obese male rats was investigated and its possible relationship with obesity-related changes in peripheral hormones was analyzed. Cafeteriadiet-overfed obese male Wistar rats with body fat percentage above $30 \%$ had a significantly decreased pituitary GH mRNA transcript level assessed by both Northern blot and in situ hybridization, and a lower pituitary GH protein level as demonstrated by immunocytochemistry. The GH transcript level correlated negatively with the serum leptin and positively with the IGF-I concentration. No differences in circulating tri-iodothyronine, non-fasting insulin
\end{abstract}

and corticosterone levels were found between overfed and control rats. GH release by cultured pituitary cells from overfed rats was comparable to that by cells prepared from control rats. In contrast, incubation of normal pituitary cells with serum from overfed rats for 3 days gave a significantly lower $\mathrm{GH}$ release than after incubation with serum from non-obese rats. In conclusion, cafeteria-dietinduced obese male Wistar rats have a decreased pituitary $\mathrm{GH}$ gene expression and a modifiable $\mathrm{GH}$ release in in vitro experiments. A possible role for peripheral circulating factors, like leptin and IGF-I, in decreasing the pituitary $\mathrm{GH}$ synthesis and release in obese rats is discussed.

Journal of Endocrinology (1998) 159, 165-172

\section{Introduction}

An imbalance between energy intake and expenditure results in humans and rodents in obesity (Mickelson et al. 1955, Sims \& Danforth 1987). Human obesity, as well as diet-induced obesity in rats, is associated with several endocrine abnormalities; a decrease in spontaneous and stimulated growth hormone $(\mathrm{GH})$ secretion has been a constant finding (Renier et al. 1990b, Cattaneo et al. 1996, De Schepper et al. 1997). A decreased pituitary GH synthesis and/or release as well as an increased GH clearance from the blood may explain the low circulating GH levels in obese rats (Dubey et al. 1988, Ahmad et al. 1989).

In the present study, we have examined in cafeteriadiet-induced obese male Wistar rats the pituitary GH mRNA levels by Northern blot and quantitative in situ hybridization, and pituitary $\mathrm{GH}$ protein expression by immunocytochemistry. Additionally, we have analyzed whether changes in pituitary GH gene expression were related to changes in several peripheral circulating hormones, known to be influenced by the obesity state and to have a potential role in pituitary GH gene expression. We have also studied in vitro, by RIA, the basal GH release from cultured pituitary cells obtained from overfed and normal rats and evaluated the influence of serum from diet-induced obese rats on the basal GH release from isolated anterior pituitary cells of normal rats.

\section{Materials and Methods}

\section{Animals}

Eighteen male Wistar rats, obtained from the Proefdierencentrum (KUL, Leuven, Belgium) were made obese by feeding them with 'cafeteria food' for 6 months from the age of 8 weeks. This 'cafeteria diet' consists of highly palatable and energy-dense foods for human consumption, such as cookies, Swiss cheese, salami, ham, crackers etc., and has a mean energy content of $10 \%$ protein, $30 \%$ carbohydrate and 60\% fat. Eighteen control rats with a similar body weight at the start of the experiment were fed with standard rat chow with a fat percentage of 3\% (A04 maintenance rat and mice diet, Usine d'Alimentation Rationnelle, F-91360 Villemoisson-sur-Orge, France). The rats were kept in a temperature-controlled environment $\left(21-23^{\circ} \mathrm{C}\right)$ with a $12 \mathrm{~h}$ light: $12 \mathrm{~h}$ darkness cycle (lights on at $0700 \mathrm{~h}$ ). Body weight of the rats in both 
groups was followed weekly and body length monthly. At 8 months of age, body composition was determined by dual energy X-ray absorptiometry. The rats were afterwards killed by $\mathrm{CO}_{2}$ inhalation in the fed state between 0930 and $1030 \mathrm{~h}$. After immediate decapitation the pituitary was rapidly dissected, frozen in dry ice-cooled isopentane and stored at $-80{ }^{\circ} \mathrm{C}$ until use. Trunk blood was collected, left clotted at room temperature for $30 \mathrm{~min}$, centrifuged and stored at $-20{ }^{\circ} \mathrm{C}$ until assay. Only pituitaries of overfed animals with a body fat percentage higher than $30 \%$ of the body weight and control rats with a percentage lower than $25 \%$ were included in the experiments. Pituitaries of five overfed rats and five control animals were pooled for RNA extraction, pituitaries of another five overfed and five control rats were used for in situ hybridization, and pituitaries of four overfed and four control rats used for the GH releasing studies. We used the pituitaries from four normally fed 2-month-old male Wistar rats for the in vitro study on the influence of serum from the killed overfed animals and control rats on basal GH release.

\section{Body composition analysis}

Total body fat mass of the rats was determined in vivo with a commercial absorptiometer (Hologic QDR 1000/W, Hologic, Waltham, MA, USA) using a specifically designed platform and software version for small animals (Rozenberg et al. 1995). In our laboratory this method has an in vivo accuracy of $5 \%$ for body fat.

\section{In situ hybridization}

Seven-micrometer pituitary sections were cut with a cryostat and mounted on slides coated with 3aminopropyltriethoxysilane (APES, 2\% APES in acetone, Sigma, St Louis, MO, USA). They were stored at $-20{ }^{\circ} \mathrm{C}$ until use. The mounted tissues were fixed for $5 \mathrm{~min}$ in $4 \%$ paraformaldehyde in PBS, rinsed in PBS, dehydrated in graded concentrations of ethanol and then air dried. The rat $\mathrm{GH}(\mathrm{rGH})$ cDNA (kindly provided by Prof. J Martial, University of Liege, Belgium) was labeled with ${ }^{35} \mathrm{~S}$ by the random priming method (Random Priming Labeling Kit, Boehringer Mannheim, Mannheim, Germany), using ${ }^{35} \mathrm{~S}$-dATP to a specific activity of $5 \times 10^{8}$ d.p.m. $/ \mathrm{mg}$. Slides were prehybridized in a humid chamber for $2 \mathrm{~h}$ at $37^{\circ} \mathrm{C}$ in a solution containing $50 \%$ deionized formamide (Fluka, Darmstadt, Germany), $1 \times$ Denhardt's solution $(50 \times$ Denhardt's solution is $1 \%$ Ficoll, 1\% polyvinylpyrrolidone, 1\% BSA, pentax Fraction $\mathrm{V}), 2 \times \mathrm{SSC}(1 \times \mathrm{SSC}$ is $15 \mathrm{mM}$ sodium citrate, $0 \cdot 15 \mathrm{M}$ $\mathrm{NaCl}), 250 \mathrm{mg} / \mathrm{ml}$ heat-denatured salmon sperm DNA, $200 \mathrm{mg} / \mathrm{ml}$ transfer RNA, and $200 \mu \mathrm{g} / \mathrm{ml}$ polyriboadenosine. Prehybridization solution was removed by suction and the tissues covered with $40 \mathrm{ml}$ of the heatdenatured labeled GH cDNA probe $(150000$ c.p.m. of the probe) in the prehybridization solution supplemented with $10 \%$ dextran sulfate and $500 \mathrm{mg} / \mathrm{ml}$ deoxynucleotide triphosphates. Dithiothreitol $(10 \mathrm{mM})$ was included with ${ }^{35}$ S-probes. Hybridization was performed in a humid chamber at $37^{\circ} \mathrm{C}$ for $16 \mathrm{~h}$. The slides were subsequently washed for $1 \mathrm{~h}$ in the same formamide buffer at $37^{\circ} \mathrm{C}$ with two changes, then with SSC $1 \times, 0.5 \times, 0.2 \times$ for $1 \mathrm{~h}$ each at room temperature. Afterwards, the slides were dehydrated in graded ethanol $/ 0.3 \mathrm{M}$ ammonium acetate, $\mathrm{pH} 7 \cdot 0$, for $10 \mathrm{~min}$. Control staining included the pretreatment of the slides with RNAse in the prehybridization mix, and hybridization of the pituitary tissue with an irrelevant probe such as albumin cDNA. The slides were air-dried and then immersed in Ilford $\mathrm{K} 2$ emulsion diluted with the same volume of $0.6 \mathrm{M}$ ammonium acetate, $\mathrm{pH}$ $7 \cdot 0$, at $42{ }^{\circ} \mathrm{C}$ and dried at $37^{\circ} \mathrm{C}$ for $10 \mathrm{~min}$ in the dark. After appropriate exposure times slides were developed in Kodak D19 developer for 4 min and fixed in 30\% sodium thiosulfate. The slides were then lightly stained with hematoxylin and examined by light microscopy. Automatic quantification was performed with a VICOM digital image processor (San Jose, CA, USA), extended with a VISIOMORPH morphoprocessor board (Morpho Systèmes, Les Ulis, France). Images with a resolution of 3.5 pixels $/ \mathrm{mm}$ were acquired through a $\mathrm{BOSCH}$ T1 VK9B1 camera (Darmstadt, West Germany), mounted on a Zeiss photomicroscope (Carl Zeiss, New York, NY, USA). Signal to noise ratios were enhanced by integrating 32 videoframes. Shade correction is inherent to the computation of absorbance images from the input scene, the camera dark current and the background reference. Grain detection was achieved with graytone peak thinning, so that each grain was ultimately reduced to a single pixel.

\section{Northern blot hybridization}

Total RNA was isolated from pooled pituitary tissue (from five overfed obese and five control lean rats) by the guanidinium thiocyanate/ $\mathrm{CsCl}$ method (Glisin et al. 1974). The tissues were gently homogenized at $0{ }^{\circ} \mathrm{C}$ with an ULTRA-TURRAX homogenizer in $3 \mathrm{ml}$ volumes of buffer $(0 \cdot 1 \mathrm{M}$ Tris- $\mathrm{HCl}, \mathrm{pH} 8$, guanidinium thiocyanate $4 \mathrm{M}$ ), then $8 \mathrm{ml}$ buffer were added and the suspension centrifuged at $5000 \mathrm{~g}$ for $10 \mathrm{~min}$ at room temperature. Afterwards $250 \mu \mathrm{l}$ sarcosyl (20\%) and $1 \mathrm{~g} \mathrm{CsCl}$ were added to the supernatant and mixed until all of the $\mathrm{CsCl}$ had dissolved. The homogenate was then layered onto $6 \mathrm{ml}$ $\mathrm{CsCl}$ solution $(\mathrm{CsCl} 5.7 \mathrm{M} /$ EDTA $0.01 \mathrm{M}$, pH 7.5) cushion in a cellulose nitrate centrifuge tube and the tube was centrifuged in a Beckman SW $27 \mathrm{~L}$ rotor at 25000 r.p.m. for $12 \mathrm{~h}$ at $25^{\circ} \mathrm{C}$. After centrifugation, the DNA band at the interface of the two $\mathrm{CsCl}$ solutions was removed with a Pasteur pipet. The tube was inverted, and all but the bottom $1 \mathrm{~cm}$ was sheared off. The RNA in the clear pellet was then washed with $500 \mathrm{ml}$ 70\% ethanol, 
air dried for $10 \mathrm{~min}$, resuspended in $400 \mathrm{ml}$ TES (Tris$\mathrm{HCl}, 10 \mathrm{mM}$; EDTA, $1 \mathrm{mM} \mathrm{pH} 7 \cdot 4$ with SDS $0 \cdot 1 \%$ ), $40 \mathrm{ml}$ sodium acetate $2.5 \mathrm{M}, 1 \mathrm{ml}$ ethanol and kept at $-70{ }^{\circ} \mathrm{C}$ for $1 \mathrm{~h}$, then the mixture was microcentrifuged at $4{ }^{\circ} \mathrm{C}$ for $30 \mathrm{~min}$. The pellet was washed with $500 \mathrm{ml}$ $70 \%$ ethanol and microcentrifuged as described above but for $15 \mathrm{~min}$. The pellet was then dried and dissolved in water.

Aliquots of total RNA (15 mg/aliquot) were denatured and subjected to electrophoresis in a 1\% agarose gel containing $2 \cdot 2 \mathrm{M}$ formaldehyde, and transferred to a nylon membrane (Amersham, Bucks, UK). rGH cDNA was labeled with a Random Primed DNA Labeling Kit (Boehringer Mannheim) with $\left[\alpha-{ }^{32} \mathrm{P}\right] \mathrm{dCTP}$. Nitrocellulose filters were prehybridized in a solution containing 40\% formamide (deionized), $5 \times$ Denhardt's solution, salmon sperm DNA $100 \mathrm{mg} / \mathrm{ml}, 5 \times$ SSC, $1 \%$ SDS at $42{ }^{\circ} \mathrm{C}$ for $4 \mathrm{~h}$. The hybridization was performed in the same solution utilized for the prehybridization supplemented with dextran sulfate $10 \%$ and containing the ${ }^{32} \mathrm{P}-$ labeled rGH cDNA. The hybridization was carried out at $42{ }^{\circ} \mathrm{C}$ for $18 \mathrm{~h}$ and the filters were washed once for $15 \mathrm{~min}$ in $2 \times \mathrm{SSC}$ in $0 \cdot 1 \% \mathrm{SDS}(\mathrm{w} / \mathrm{v})$ at room temperature, twice for $15 \mathrm{~min}$ in $2 \times \mathrm{SSC}$ in $0 \cdot 1 \% \mathrm{SDS}$ at $65^{\circ} \mathrm{C}$, twice for $15 \mathrm{~min}$ in $1 \times \mathrm{SSC}$ in $0.1 \%$ SDS at $65^{\circ} \mathrm{C}$ and once for $15 \mathrm{~min}$ in $0 \cdot 2 \times \mathrm{SSC}$ in $0 \cdot 1 \% \mathrm{SDS}$ at $65^{\circ} \mathrm{C}$. The filter was exposed to Kodak X-Qmat AR film (Eastman Kodak, Rochester, NY, USA) at $-80{ }^{\circ} \mathrm{C}$ using an intensifying screen. The filter was then washed with $0 \cdot 01 \times \mathrm{SSC}+0 \cdot 01 \% \mathrm{SDS}$ for $5 \mathrm{~min}$ at $100{ }^{\circ} \mathrm{C}$ to remove the probes. After washing, subsequent hybridization with a $\beta$-actin cDNA probe was performed as a control to monitor total RNA. Bands of the autoradiograms were quantified by Ultroscan XL densitometer scanning (Pharmacia, Uppsala, Sweden).

\section{Immunocytochemistry}

For immunocytochemical studies, slides were dried at room temperature and sections were fixed with paraformaldehyde (4\% in PBS at $\mathrm{pH} 7 \cdot 4$ ) and washed in PBS. Sections were preincubated with $0.5 \%$ BSA in PBS, for $20 \mathrm{~min}$ at room temperature and then incubated overnight at $4{ }^{\circ} \mathrm{C}$ with $200 \mu \mathrm{l}$ monkey anti-rGH (UCB-Bioproducts SA, Braine-l'-Alleud, Belgium). After washing in PBS, sections were incubated with the second antibody (goat anti-monkey conjugated to peroxidase) for $30 \mathrm{~min}$ at room temperature and the reaction was disclosed with the substrate 3,3'-diaminobenzindine (Sigma) in Tris-buffered saline (Tris- $\mathrm{HCl}, 25 \mathrm{mM}$; NaCl, 0.14 M; KCL, $2.7 \mathrm{mM}$ ) $\mathrm{pH} 7 \cdot 6$ with $0 \cdot 025 \% \mathrm{H}_{2} \mathrm{O}_{2}$ (brown precipitation peroxidase activity) and then analyzed using light microscopy. To evaluate the specificity of immunochemical staining, a competition experiment was performed with the primary antibody preincubated with $\mathrm{GH}$.
In vitro study

Cell preparation The anterior pituitaries from control and overfed obese rats were minced and shaken at $37^{\circ} \mathrm{C}$ successively in: (1) Dulbecco's modified Eagle's medium (DMEM) (Gibco, Grand Island, NY, USA), Hepes $15 \mathrm{mM}$; BSA $0 \cdot 3 \%$ (Sigma), supplemented with $0 \cdot 5 \%$ trypsin (w/v) (Boehringer Mannheim) for $10 \mathrm{~min}$, (2) for $1 \mathrm{~min}$ in buffer plus 0.0001\% deoxyribonuclease (w/v; grade II) (Boehringer Mannheim), and (3) for $5 \mathrm{~min}$ in buffer plus $0.1 \%$ soybean trypsin inhibitor $(\mathrm{w} / \mathrm{v})$ (Calbiochem, San Diego, CA, USA). Tissue was subsequently incubated in the same buffer supplemented with $2 \mathrm{mM}$ EDTA and finally in $\mathrm{Ca}^{2+}$ - and $\mathrm{Mg}^{2+}$-free Eagle's balanced salt solution containing $1 \mathrm{mM}$ EDTA. After washing in this last medium, cells were finally dispersed mechanically. The cell suspension was then filtered through a nylon gauze $(50 \mathrm{~mm}$ mesh), collected and centrifuged at $250 \mathrm{~g}$ for $10 \mathrm{~min}$. The cell pellet was resuspended in DMEM. Cell recovery was estimated per gland and cell viability measured by neutral red dye uptake (final dye concentration $0 \cdot 01 \%, \mathrm{w} / \mathrm{v}$ ).

Cell culture The cells were resuspended in culture medium (DMEM supplemented with $1 \mathrm{~g} / 1 \mathrm{NaHCO}_{3}$, 0.015 M Hepes and 0.015 M TES (Calbiochem) and 10\% newborn calf serum (Gibco), $35 \mu \mathrm{g} / \mathrm{ml}$ penicillin, and $50 \mu \mathrm{g} / \mathrm{ml}$ streptomycin (Sigma)) adjusted to $\mathrm{pH} 7 \cdot 5$; and plated at a density of $2 \times 10^{6}$ cells per uncoated Petri dish (15 mm Falcon, Oxnard, CA, USA). Cells were cultured for up to 3 days in a humidified $5 \% \mathrm{CO}_{2}$ incubator at $37^{\circ} \mathrm{C}$. On the third day of culture, cells obtained from obese and control rats were washed with DMEM/BSA $0.5 \%$ three times after which cells were incubated for $3 \mathrm{~h}$ in DMEM/BSA $0.5 \%$; the medium was then collected for GH assay.

In a second type of experiment, pituitary cells from four normally fed 2-month-old male Wistar rats were prepared as described above and incubated with medium supplemented with serum from either overfed or control rats at a concentration of $20 \%$ for 3 days, after which the culture medium was collected for GH assay.

\section{RIA}

The GH concentration was measured by a standard double antibody RIA as described previously (De Schepper et al. 1997). The anti-rGH antibody, as well as the rGH Rp2 standard, was obtained from the National Institute of Diabetes, Digestive and Kidney Diseases (Bethesda, MD, USA). The range of assay detectability is $1-600 \mathrm{ng} / \mathrm{ml}$. Samples exceeding this upper limit were diluted in phosphate buffer and reassayed. Inter- and intra-assay coefficients of variation were less than $10 \%$.

Insulin concentration was measured by RIA as previously described (Pipeleers et al. 1985). 
Table 1 Results of body composition analysis in overfed and control rats

\begin{tabular}{|c|c|c|c|}
\hline & $\begin{array}{l}\text { Overfed rats } \\
(n=18)\end{array}$ & $\begin{array}{l}\text { Control rats } \\
(n=18)\end{array}$ & $P$ value \\
\hline $\begin{array}{l}\text { Total body mass } \\
\text { (g) }\end{array}$ & $498 \pm 13$ & $409 \pm 8 \cdot 2$ & $<0.001$ \\
\hline Body fat mass & & & \\
\hline (g) & $177 \cdot 4 \pm 12 \cdot 7$ & $96 \cdot 7 \pm 6 \cdot 1$ & $<0 \cdot 0001$ \\
\hline$(\%)$ & $35 \pm 1 \cdot 9$ & $23 \pm 1 \cdot 2$ & $<0 \cdot 001$ \\
\hline Body lean mass & $308 \cdot 5+6 \cdot 5$ & $301 \cdot 2+7 \cdot 1$ & NS \\
\hline
\end{tabular}

NS, not significant.

Commercial RIAs were used for the measurement of rat insulin-like growth factor-I (rIGF-I) (Rat IGF-I, Diagnostic System Laboratories Inc., Flanders, NJ, USA), rat corticosterone (Rat Corticosterone Assay System, Amersham) and rat leptin (Rat Leptin RIA, Linco Research Inc., St Charles, MO, USA). Free triiodothyronine $\left(\mathrm{FT}_{3}\right)$ was measured by a commercial microparticle enzyme immunoassay (AXSYM Free $T_{3}$, Abbott Lab., Abbot Parck, IL, USA). The RIA for rIGF-I uses an antiserum specific for rIGF-I coupled with rIGF-I standards and includes an acid-ethanol extraction which gives virtually $100 \%$ recovery of endogenous rIGF-I as compared with acid chromatography.

\section{Statistical analysis}

Results are presented as means \pm S.E.M. Statistical differences between groups were determined using Student's $t$-test and correlations between different parameters by linear regression analysis. Statistical significance was considered at $P<0 \cdot 05$.

\section{Results}

Body composition

After 6 months of overfeeding, the cafeteria-diet-overfed rats had a significantly higher mean total body mass $(498 \pm 13$ vs $409 \pm 8 \mathrm{~g}, P<0 \cdot 001)$, a higher mean body fat mass $(177 \cdot 4 \pm 12.7$ vs $96.7 \pm 6.1 \mathrm{~g} ; P<0 \cdot 0001)$ and a
L O

\section{$\mathrm{GH}$ mRNA $\longrightarrow$ (1000 bp)}
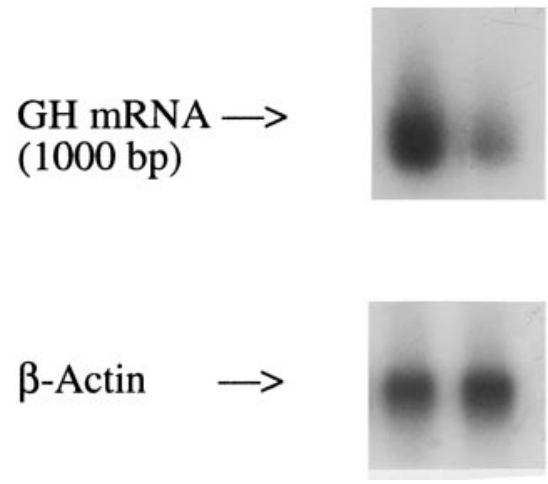

Figure 1 Northern blot analysis of pituitary GH mRNA levels. Total RNA was obtained from pooled pituitaries from five obese $(\mathrm{O})$ and five lean rats (L). The GH mRNA levels were standardized by $\beta$-actin mRNA levels.

higher mean body fat percentage ( $35 \pm 1 \cdot 9$ vs $23 \pm 1 \cdot 2 \%$, $P<0 \cdot 001)$ as compared with the control rats (Table 1 ). There was no difference in mean body lean mass between the two groups. All but four cafeteria-diet-fed rats had a body fat percentage above $30 \%$ and only four control fed rats had a body fat percentage above $25 \%$.

\section{Hormonal measurements}

Between the overfed rats and control rats, no differences were measured in non-fasting serum insulin, $\mathrm{FT}_{3}$ and corticosterone levels at the moment of decapitation (Table 2). Mean IGF-I concentration was, however, significantly lower in the cafeteria-diet-fed group $(1471 \pm 75$ vs $1872 \pm 102 \mu \mathrm{g} / 1, P<0 \cdot 005)$, while mean leptin concentration was significantly higher $(24 \cdot 3 \pm 3 \cdot 8$ vs $7 \cdot 5 \pm$ $0 \cdot 5 \mu \mathrm{g} / 1, P<0 \cdot 0001)$.

\section{Pituitary GH gene expression}

Northern blot analysis of pooled pituitary GH mRNA showed that the mean GH transcript level in overfed rats was $41 \%$ of the level in the control lean rats (Fig. 1).

Table 2 Results of the circulating hormone levels in overfed and control rats

\begin{tabular}{|c|c|c|c|}
\hline & $\begin{array}{l}\text { Overfed rats } \\
(n=18)\end{array}$ & $\begin{array}{l}\text { Control rats } \\
(n=18)\end{array}$ & $P$ value \\
\hline IGF-I $(\mu \mathrm{g} / \mathrm{l})$ & $1471 \pm 75$ & $1872 \pm 102$ & 0.005 \\
\hline $\mathrm{FT}_{3}(\mathrm{ng} / \mathrm{l})$ & $3 \cdot 7 \pm 0 \cdot 18$ & $3 \cdot 6 \pm 0 \cdot 16$ & NS \\
\hline Insulin (ng/l) & $2872 \pm 272$ & $3491 \pm 270$ & NS \\
\hline Corticosterone (ng/l) & $440 \pm 41$ & $347 \pm 35$ & NS \\
\hline Leptin $(\mu \mathrm{g} / \mathrm{l})$ & $24 \cdot 3 \pm 3 \cdot 8$ & $7 \cdot 5 \pm 0 \cdot 5$ & $0 \cdot 0001$ \\
\hline
\end{tabular}

NS, not significant. 

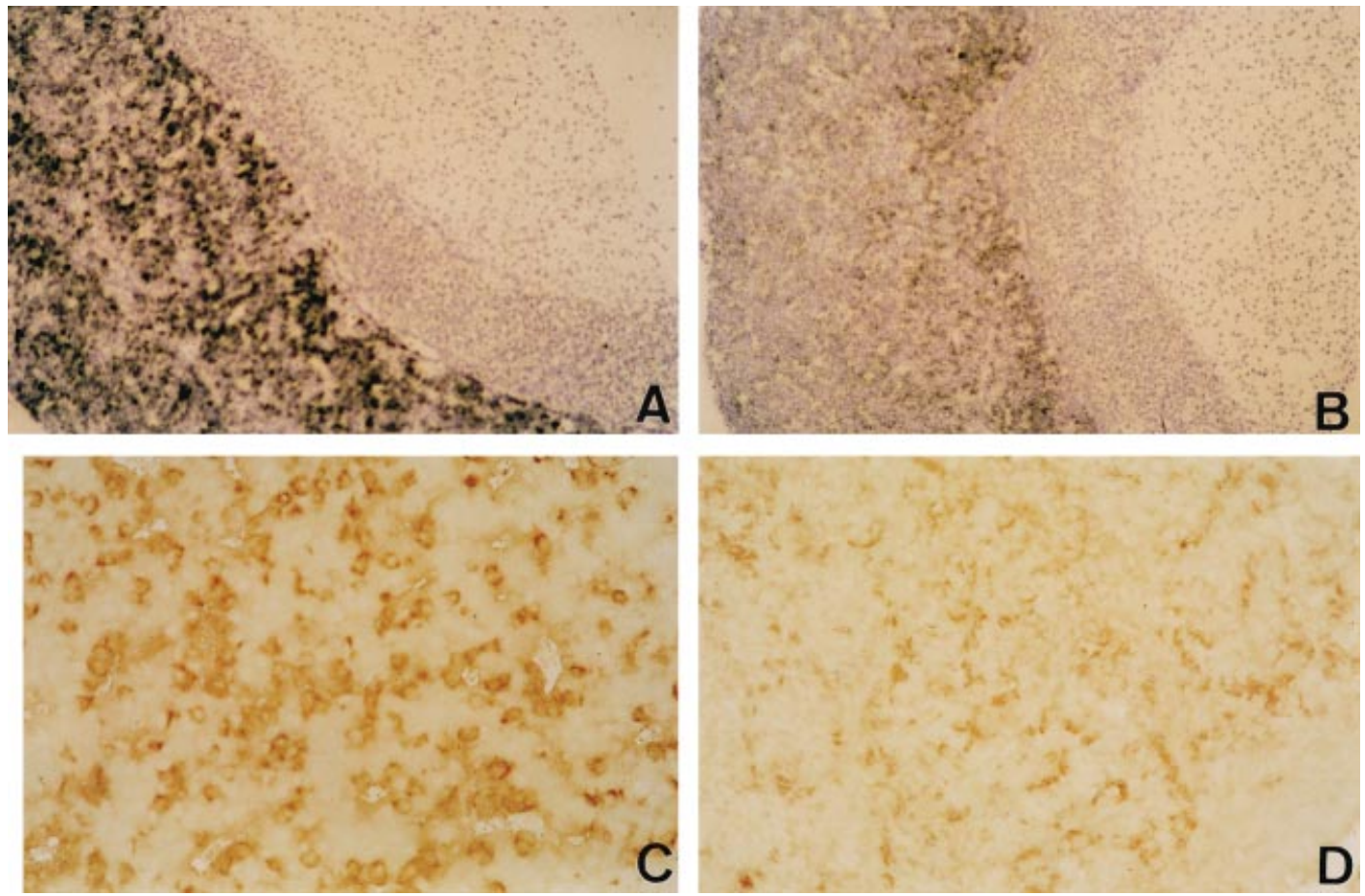

Figure 2 Pituitary sections from obese $(B, D)$ and lean rats $(A, C)$ : comparison of $G H$ mRNA accumulation by in situ hybridization (A, B) and GH protein expression by immunocytochemistry (C, D). Magnification: A, B: $\times 50$; C, D: $\times 100$.

In situ hybridization showed that the density of silver grains overlying the cells in the anterior lobe of the pituitaries in overfed rats was lower in comparison with that in control rats (Fig. 2A and B). The intensity of hybridization signals was significantly lower in tissue sections of overfed rats than in those of control rats $\left(3663 \pm 315\right.$ vs $5226 \pm 351$ silver grains $/ 0 \cdot 02 \mathrm{~mm}^{2}$, $P<0 \cdot 0001)$. There was no detectable hybridization signal when sections were preincubated in RNase or hybridized with an irrelevant probe $\left({ }^{35} \mathrm{~S}\right.$-labeled albumin probe).

GH mRNA level as quantified by in situ hybridization correlated negatively with the leptin level $(r=-0 \cdot 80$, $P<0 \cdot 005)$ and positively with the IGF-I concentration $(r=0 \cdot 65, P<0 \cdot 05)$. No correlation was found between the pituitary GH mRNA transcript level and circulating insulin, $\mathrm{FT}_{3}$ or corticosterone.

\section{Pituitary GH protein content}

As shown in Fig. 2, the immunoreactive GH staining of the pituitary sections obtained from overfed rats was markedly decreased as compared with that of the control rats (Fig. 2C and D). In a competition experiment, no staining was observed.

\section{Pituitary GH release}

No significant difference was seen in GH output between the pituitary cells of the overfed rats and those of control rats when cultured for $3 \mathrm{~h}$ in DMEM/BSA 0.5\% (66 \pm 10 vs $44 \pm 6 \mathrm{ng} / \mathrm{ml}$ per $3 \mathrm{~h}$, NS).

The pituitary cells of normal Wistar rats had significantly lower GH output after incubation in serum from obese rats than after incubation in serum from control rats $(970 \pm 40$ vs $2140 \pm 80 \mathrm{ng} / \mathrm{ml}, P<0 \cdot 0001)$.

\section{Discussion}

We have previously reported that the spontaneous pulsatile $\mathrm{GH}$ secretion, assessed by repetitive blood sampling, is decreased in cafeteria-diet-induced obese male Wistar rats (De Schepper et al. 1997). In an attempt to determine the molecular basis of this abnormality, we have compared the levels of GH mRNA in the pituitaries of overfed and control rats.

We confirmed by two techniques (Northern blot and quantitative in situ hybridization) a significantly lower $\mathrm{GH}$ transcript level in the pituitaries of diet-induced obese male rats as compared with the level in pituitaries from lean control rats. This finding is inconsistent with the results of a 
recent dot blot hybridization study performed in 7-monthdiet-induced obese male rats, showing a similar pituitary GH transcript level in obese and lean animals (Cattaneo et al. 1997). In that study no direct measurements of the degree of fat mass accumulation were made, but an obesity index based on weight and length measurements was used. Furthermore, another strain of laboratory rat (SpragueDawley) was used in that experiment. Since Wistar rats as compared with Sprague-Dawley rats, fed with a high fat ration diet for 20 weeks from weaning on, were found to have a much higher body fat percentage, as determined by carcass analysis (Schemmel et al. 1970), and since in our experiment using Wistar rats, the pituitary GH mRNA accumulation was related to the body fat percentage, we suspect that Wistar rats might be more sensitive to developing an impaired GH gene expression after cafeteria-diet overfeeding. However, we cannot exclude an influence of the type of feeding on the $\mathrm{GH}$ gene expression; it has indeed been shown that a high fat ration diet, as in our experiment, as compared with a sucrose-containing diet, gives a higher degree of nitrogen retention and lower levels of several liver enzymes (Dror et al. 1973), while high-fat as compared with low-fat cafeteria food induces higher insulin levels in old animals (Harris 1993). In our study the rats were killed shortly after feeding, making differences in serum insulin concentration less obvious, but probably the existence of a decreased GH gene expression more clear, since fasting decreases $\mathrm{GH}$ gene expression in normal rats (Rodriguez et al. 1995). No information about the time of pituitary removal in relation to feeding is available in the study with overfed Sprague-Dawley rats.

The finding of a decreased pituitary GH mRNA signal could be due to a decreased number of somatotrophs or to a lower level of GH transcripts per somatotroph. Our molecular biology data from both in situ hybridization and Northern blot analysis cannot differentiate between these two possibilities. We hypothesized that a lower pituitary GH gene transcript level in overfed rats might be related to the changes in circulating hormones. It has been shown that not only the number of somatotrophs in normal animals, but also the GH gene expression can be influenced by hormonal manipulations (Hemming et al. 1984, Namba et al. 1989, Martinoli et al. 1991). Thyroid hormone can increase not only the number of somatotrophs, but also the pituitary GH gene expression (Martinoli \& Pelletier 1989). Also corticosterone is important in somatotroph differentiation and in increasing GH gene expression as shown by in vitro experiments (Evans et al. 1982, Martinoli \& Pelletier 1989). Insulin can have both a stimulatory and inhibitory effect on GH gene expression in pituitary cell lines, depending on the culture conditions, while IGF-I has clearly a negative effect on pituitary GH gene expression (Yamashita \& Melmed 1986, Isaacs et al. 1987). We could not, however, ascribe this lower pituitary GH transcript level in our study to hormonal alterations, since in our study circulating IGF-I and insulin, known to influence negatively the GH secretion, were lower or unchanged in the overfed rats and the stimulatory hormonal factors for GH gene transcription, thyroid hormone and corticosteroid, were not decreased in the overfed obese rats. In a recent study of cafeteria-diet-induced obesity in female Sprague-Dawley rats, circulating insulin and IGF-I levels were comparable with the levels in control-fed non-obese rats (Cattaneo et al. 1997). In obese rats, as in obese humans, RIAs for IGF-I levels appear to show controversial results, even if performed in the same laboratory (Cocchi et al. 1993). The use of different IGF-I standards and of different sources of antibodies, and the use of different methods for the removal of the IGF-I binding proteins could explain the differences in the results obtained. After acid-ethanol extraction, as performed in our experiment, residual binding proteins may persist, but when a high affinity antibody is used they probably do not interfere with IGF measurement by RIA. While the obese male Wistar rats presented with low total IGF-I levels in our experiments, we cannot exclude the possibility that they exhibit relatively increased free IGF-I levels, due to suppression of certain IGF-binding proteins. Information on IGF-I binding proteins in obese rats is scarce and further studies are needed to interpret correctly the GH-IGF-I regulation in overfeeding conditions (Nguyen-yamamoto et al. 1994). On the other hand, in overfed obese rats low IGF-I levels are, however, not unexpected, since circulating $\mathrm{GH}$, known to be decreased in diet-induced obesity, is the major regulator of serum IGF-I level in rats. Furthermore, we found a positive correlation between the circulating IGF-I level and pituitary GH transcript level.

Our immunocytochemistry data demonstrated a clearly lower GH protein staining in pituitaries of overfed obese male Wistar rats. In contrast, the pituitary GH content of overfed male Sprague-Dawley rats, as assayed by RIA after homogenization, was found to be similar to that of control fed rats (Renier et al. 1990b). The determination of the pituitary $\mathrm{GH}$ content in relation to the pituitary weight in this study is probably not appropriate for evaluating the pituitary $\mathrm{GH}$ protein production, since changes in pituitary weight might be due to changes in the number not only of somatotrophs, but also of other pituitary cells. Furthermore, the use of different rat strains and different feeding protocols might explain also the differences in pituitary GH content observed between overfeeding studies.

Since both GH protein and GH mRNA levels were lower in the pituitaries of overfed obese animals, our data suggest that overfed animals with obesity exhibit a decreased pituitary GH synthesis. In contrast, our in vitro data on $\mathrm{GH}$ release during $3 \mathrm{~h}$ showed no difference in $\mathrm{GH}$ secretion of cultured pituitary cells between overfed or control rats. The discrepancy observed between in vivo and in vitro results can be explained by our culture method itself. The measurement of GH output after $3 \mathrm{~h}$ of culture, 
the use of dispersed pituitary cells and culturing in a medium without significant amounts of hormones involved in GH release may explain the different results obtained. Furthermore, the finding that basal GH release from cultured pituitary cells was significantly lower after incubation with serum from overfed rats, as compared with the serum of control fed rats, confirmed our speculation that changes in circulating hormones might be at least partially responsible for the blunted $\mathrm{GH}$ secretion in the obese rats. Incubation of pituitary cells of lean rats with serum from obese Zucker rats showed a decreased growth hormone-releasing hormone $(\mathrm{GHRH})$-stimulated $\mathrm{GH}$ release in vitro, suggesting also in this model an influence of inhibiting serum factors on pituitary GH secretion (Renier et al. 1990a).

A role of different plasma factors, such as insulin, free fatty acids (FFA), IGF-I or pancreatic somatostatin in decreasing pituitary GH synthesis, has been proposed in genetic- and diet-induced obesity models (Renier et al. 1990a). Insulin and IGF-I are probably not the major ones to be considered, since in our experiment circulating levels were not increased or even decreased. Previous studies have shown that FFA infusion blocks GHRH-stimulated GH release in vivo (Alvarez et al. 1991), but no data on effects of FFAs on basal release in in vitro culture systems are available yet. Moreover, since the suppressive effect of FFA on GH secretion in rats can be abolished by pretreatment with a specific somatostatin antiserum (Tannenbaum et al. 1978), FFAs probably exert their effect by stimulation of endogenous somatostatin secretion in rats. Finally, the role of pancreatic somatostatin is speculative, since a rise in pancreatic somatostatin in overfed rats has not been observed and most of the pancreatic somatostatin is metabolized by the liver, making it improbable that high levels of somatostatin reach the pituitary. Since it was found that serum leptin correlated positively with the body fat percentage of animals, the body fat percentage correlated negatively with the spontaneous and GHRHstimulated GH secretion (De Schepper et al. 1997) and the pituitary GH expression correlated negatively with serum leptin levels in our experiment, one might speculate that the hyperleptinemia in overfed obese rats might directly affect the pituitary GH secretion. However, the recent finding that the administration of leptin antiserum decreased the spontaneous GH secretion in freely moving fed rats, points rather to a stimulating role of leptin on the pituitary GH secretion (Carro et al. 1997). Further studies in pituitary cell cultures are necessary to determine if leptin affects indirectly the GH secretion at the level of the pituitary.

\section{Acknowledgements}

We wish to thank Dr O Louis (Department of Radiology, University of Brussels, Belgium) for performing the body composition analysis, Prof. D Pipeleers (Laboratory of Metabolism and Endocrinology, University of Brussels, Belgium) for insulin RIA and $\mathrm{Mr} M$ Callewaert and J Schietekatte (RIA Laboratory, University of Brussels, Belgium) for technical assistance with the RIA determinations. We are also grateful to Prof. J Martial (University of Liege, Belgium) for providing us with the rat $\mathrm{GH}$ cDNA. This study was supported by a grant from the Belgian Study Group of Pediatric Endocrinology (BSGPE).

\section{References}

Ahmad I, Steggles AW, Carrillo AJ \& Finkelstein JA 1989 Obesityand sex-related alterations in growth hormone messenger RNA levels. Molecular and Cellular Endocrinology 65 103-109.

Alvarez CV, Mallo F, Burguera B, Cacicedo L, Dieguez C \& Casanueva FF 1991 Evidence for a direct pituitary inhibition by free fatty acids of in vivo growth hormone responses to growth hormone-releasing hormone in the rat. Neuroendocrinology 53 185-189.

Carro E, Senaris R, Considine RV, Casanueva FF \& Dieguez C 1997 Regulation of in vivo growth hormone secretion by leptin. Endocrinology 138 2203-2206.

Cattaneo L, De Gennaro Colonna V, Zoli M, Muller E \& Cocchi D 1996 Characterization of the hypothalamo-pituitary-IGF-I axis in rats made obese by overfeeding. Journal of Endocrinology 148 347-353

Cattaneo L, De Gennaro Colonna V, Zoli M, Muller E \& Cocchi D 1997 Hypothalamo-pituitary-IGF-I axis in female rats made obese by overfeeding. Life Sciences 61 881-889.

Cocchi D, Parenti M, Cattaneo L, De Gennaro Colonna V, Zocchetti A \& Muller EE 1993 Growth hormone secretion is differently affected in genetically obese male and female rats. Neuroendocrinology 57 928-934.

De Schepper J, Smitz J, Zhou X, Louis O, Velkeniers B \& Vanhaelst L 1997 Cafeteria diet-induced obesity is associated with a low spontaneous growth hormone secretion and normal plasma insulin-like growth factor-I concentrations. Growth Regulation 7 1-8.

Dror Y, Sassoon HF, Watson JJ, Mack DO \& Johnson BC 1973 Fat versus sucrose as the nonprotein calorie portion of the diet of rats. Journal of Nutrition 103 342-346.

Dubey AK, Hanukoglu A, Hansen BC \& Kowarski AA 1988 Metabolic clearance rates of synthetic human growth hormone in lean and obese male rhesus monkeys. Journal of Clinical Endocrinology and Metabolism 67 1064-1067.

Evans RM, Birnberg NC \& Rosenfeld MG 1982 Glucocorticoid and thyroid hormones transcriptionally regulate growth hormone gene expression. Proceedings of the National Academy of Sciences of the USA 79 7659-7663.

Glisin V, Crkienjakov R \& Byus C 1974 Ribonucleic acid isolated by cesium chloride centrifugation. Biochemistry 13 2633-2637.

Harris RBS 1993 The impact of high- or low-fat cafeteria foods on nutrient intake and growth of rats consuming a diet containing $30 \%$ energy as fat. International Journal of Obesity 17 307-315.

Hemming FJ, Begeot M, Dubois MP \& Dubois PM 1984 Fetal rat somatotropes in vitro: effects of insulin, cortisol, and growth hormone releasing factor on their differentiation: a light and electron microscopic study. Endocrinology 114 2107-2113.

Isaacs RE, Gardner DG \& Baxter JD 1987 Insulin regulation of growth hormone gene expression. Endocrinology 120 2022-2028.

Martinoli ME \& Pelletier G 1989 Thyroid and glucocorticoid hormone regulation of rat pituitary growth hormone messenger ribonucleic acid as revealed by in situ hybridization. Endocrinology 125 1246-1252. 
Martinoli ME, Veilleux R \& Pelletier G 1991 Effects of triiodothyronine, dexamethasone and estradiol- $17 \beta$ on GH mRNA in rat pituitary cells in culture as revealed by in situ hybridization. Acta Endocrinologica 124 83-90.

Mickelson O, Tabahoshi S \& Craig C 1955 Experimental obesity I. Production of obesity in rats by feeding high fat diets. Journal of Nutrition 57 541-554.

Namba H, Morita S \& Melmed S 1989 Insulin-like growth factor-I action on growth hormone secretion and messenger ribonucleic acid levels: interaction with somatostatin. Endocrinology 124 1794-1799.

Nguyen-yamamoto L, Deal CL, Finkelstein JA \& Van Vliet G 1994 Hormonal control of growth in the genetically obese Zucker rat. I. Linear growth, plasma insulin-like growth factor-I (IGF-I) and IGF-binding proteins. Endocrinology 134 1382-1388.

Pipeleers D, Schuit F, in't Veld P, Maes E, Hooghe-Peters EL, Van De Winkel M \& Gepts W 1985 Interplay of nutrients and hormones in the regulation of insulin release. Endocrinology 117 824-833.

Renier G, Gaudreau P, Deslauriers N, Petitclerc D \& Brazeau P $1990 a$ Dynamic of the GRF-induced GH response in genetically obese Zucker rats: influence of central and peripheral factors. Regulatory Peptides 28 95-106.

Renier G, Gaudreau P, Hajjad H, Deslauriers N, Houde-Nadeau M \& Brazeau P 19906 Decreased pituitary growth hormone response to growth hormone-releasing factor in cafeteria-fed rats: dietary and obesity effects. Neuroendocrinology 52 284-290.
Rodriguez M, Rodriguez F, Jolin T \& Santisteban P 1995 Comparative effects of food restriction, fasting, diabetes and thyroidectomy on growth hormone and thyrotropin gene expression in the rat pituitary. European Journal of Endocrinology 133 110-116.

Rozenberg S, Vandromme J, Neve J, Aguilera A, Muregancuro A, Peretz A, Kinthaert J \& Ham H 1995 Precision and accuracy of in vivo bone mineral measurement in rats using dual-energy $\mathrm{X}$-ray absorptiometry. Osteoporosis International 5 47-53.

Schemmel R, Mickelsen O \& Gill JL 1970 Dietary obesity in rats: body weight and body fat accretion in seven strains of rats. Journal of Nutrition 100 1041-1048.

Sims H \& Danforth E 1987 Expenditure and storage of energy in man. Journal of Clinical Investigation 79 1019-1021.

Tannenbaum GS, Epelbaum J, Colle E, Brazeau P \& Martin JB 1978 Antiserum to somatostatin reverses starvation-induced inhibition of growth hormone but not insulin secretion. Endocrinology 102 1909-1914.

Yamashita S \& Melmed S 1986 Insulin-like growth factor I action on rat anterior pituitary cells: suppression of growth hormone secretion and messenger ribonucleic acid levels. Endocrinology 118 176-182.

Received 17 September 1997

Revised manuscript received 25 February 1998

Accepted 15 May 1998 